\begin{tabular}{|c|c|}
\hline $\begin{array}{c}\text { ÇÜTAD } \\
\text { Çukurova Üniversitesi } \\
\text { Türkoloji Araștırmaları Dergisi }\end{array}$ & $\begin{array}{c}\text { Cilt 6, Sayı } 1 \\
\text { Haziran } 2021\end{array}$ \\
\hline $\begin{array}{l}\text { ISSN: 2587-1900 } \\
\text { E-ISSN: 2548-0979 }\end{array}$ & $\begin{array}{l}\text { Geliş Tarihi: } 09.11 .2020 \\
\text { Kabul Tarihi: } 31.05 .2021\end{array}$ \\
\hline \multicolumn{2}{|c|}{$\begin{array}{l}\text { Makale Künyesi (Araştırma): Çöltü, İ. (2021). Canan Tan ve Nur } \\
\text { İçözü'nün bellek romanlarında göç ve aşk mübadelesi üzerine bir } \\
\text { karşlaştırma. Çukurova Üniversitesi Türkoloji Araştırmaları Dergisi, } \\
6(1), 222-246 \text {. }\end{array}$} \\
\hline \multicolumn{2}{|c|}{ https://doi.org/10.32321/cutad.823699 } \\
\hline
\end{tabular}

\title{
CANAN TAN VE NUR İÇÖZÜ'NÜN BELLEK ROMANLARINDA GÖÇ VE AŞK MÜBADELESİ ÜZERINE BİR KARŞILAŞTIRMA
}

\section{ÖZET}

İlker ÇÖLTÜ ${ }^{1}$

Göç etmek zorunda bırakılmış insanların yaşadıkları travmalardan biri de uğruna her şeyin göze alındığı ve pek çok şeyin feda edildiği sevgiliden, belki bir daha hiç görüşmemek üzere ayrılmaktır. İnsanın doğup büyüdüğü ve bahçesinde koştuğu evi terk edip oraları bir daha görememesi, en yakınlarından ayrılması da diğer bir travmatik yaşantıdır. Bu çalışmada Türk kadın yazarlardan Canan Tan'ın "Hasret” ve Nur İçözü’nün "Hürriyet” adlı anıya dayalı bellek romanları karşılaştırılmaktadır. Her iki yazarın eseri, 1900’lü yılların başında gerçekleşen Balkan Savaşları ile Birinci Dünya Savaşı ve Kurtuluş Savaşı'nda yaşanan zorlukları, travmaları, ekonomik çöküntüyü, göç etme mecburiyetini, güç kaybını ve yabancılaşmayı dile getirir. Savaş sonrası Lozan mübadelesi ile göç etmek zorunda kalan Türk ve Yunan diyesi Rum halkının göç sonrası karşılaştıkları hoşgörü yoksunluğu ele alınmaktadır. Her iki eserde de birbirlerine bir türlü kavuşamayan Rum ve Türk âşıkların hazin aşk hikâyeleri göç unsurunun yıkıcılığı bağlamında irdelenip aşkın mübadelesinde sevginin farklı dil, din veya ırk tanımadığı konusuna eleştirel bakış açısı sunulmaktadır.

Anahtar kelimeler: Sevgi, göç, yabancılaşma, aşk, mübadele, bellek roman1.

\section{A COMPARISON OF MIGRATION AND LOVE EXCHANCE IN MEMORY NOVELS, CANAN TAN AND NUR İÇÖZÜ}

\section{ABSTRACT}

One of the traumas experienced by people who have been forced to migrate is to leave the lover, for whom everything has been taken

1 Çukurova Üniversitesi, Yabancı Diller Yüksekokulu, Dr. Öğr. Üyesi. icoltu@gmail.com https://orcid.org/0000-0003-4568-3610 


$\begin{array}{cc}\text { ÇÜTAD } & \text { Canan Tan ve Nur İçözü’nün Bellek Romanlarında } \\ \text { Haziran 2021 } & \text { Göç ve Aşk Mübadelesi Üzerine Bir Karşıllaştırma }\end{array}$

\begin{abstract}
for granted and so much has been sacrificed, perhaps never to meet again. Another traumatic experience is the inability of a person to leave the house in which he was born, grown up and run in his garden without seeing there again and leave their closest relatives. In this study, memory novels based on the memoir, "Hasret" by Turkish female writer Canan Tan and "Hürriyet" by Nur İçözü, are compared. The works of both authors express the difficulties experienced during the Balkan Wars, the First World War and the War of Independence in the early 1900s, traumas, economic collapse, the need to migrate, loss of power and alienation. The lack of tolerance faced by the Greek and Turkish people who had to immigrate with the Lausanne exchange after the war is discussed. In both works, the heart-breaking love stories of Greek and Turkish minstrels, who could not meet each other, are examined in the context of the destructiveness of the migration factor, and a critical perspective is presented to the issue that love does not recognize a different language, religion or race in the exchange of love.
\end{abstract}

Keywords: Affection, immigration, alienation, love, exchange, memory novel.

\title{
Gíriş
}

Siyasi, ekonomik veya dinî amaçlara ulaşmak için gerçekleşen savaşlar dünya tarihinde binlerce yıla dayanır. Savaş, insanlık tarihi boyunca değişir, savaş araçlarının gelişmesi ile savaşın kapsamı genişler ve böylece insan yaşamını etkileyen yıkıcılık artar. Önceleri iki devlet arasında geçekleşen savaşlar özellikle 1900'lü yılların başında artık birçok ulusun dahil olduğu bir biçimde kendini gösterir. Birinci Dünya Savaşı (1914-1918), kendi ülkemiz de dahil olmak üzere farklı ulusların katılımı ile meydana gelir. Çok uluslu gerçekleşen bu savaşın sonucunda yıkıcılık da yüksek boyutlara ulaşır. $\mathrm{Bu}$ yıkıcılığı anımsamak ve savaşın olumsuzluğunu gelecek nesiller için adeta kayıt altına almak açısından mimari, görsel ve yazınsal sanat dallarının ortaya koyduğu eserler insanlara farklı bakış açıları sunar. Anitlar, film ve tiyatrolar ile edebiyat bu sanatlar arasinda yer alır. Savaşın yıkıcılığını anımsama yönünde diğer sanat dallarına oranla edebiyatın çok daha fazla öne çıktığı görülür. Savaş sonrası sosyolojik durum ile toplumsal-tarihsel bağlar da dikkate alınarak gelişen anı veya bellek romanları savaşların yıkıcılık boyutu farklı konular açısından ele alıp aktarır. 1900'lü yılların başındaki savaşların kendi coğrafyamız açısından en önemlileri ise Balkan Savaşları (19121913), Birinci Dünya Savaş1 (1914-1918) ve Kurtuluş Savaş1 (19191923) dır. Bu savaşların en önemli yıkıcılık boyutu ölüm temasından sonra insanların yaşadıkları göçlerdir. Göç unsurunun zaten insanlık tarihi kadar eski olduğu bilinmektedir. Bu bağlamda öncelikle göç unsuruna değinmek gerekir. 


\section{GÖÇ}

İlk insanların göçebe yaşam tarzları avcılık ve toplayıcılık üzerine kurulmuştur. Ateşin bulunması, toprağın işlenip ekilmesi ve bazı hayvanların evcilleştirilmesi ile artık yerleşik hayata geçen insan daha büyük topluluklar kurmaya başlar. İnsan her ne kadar da yerleşik hayata geçmiş denilse bile göç ve göçebe yaşamını coğrafi ve yaşamsal gerekçelerden dolayı sürdürür. İnsan göçü bazen bireyin kendi isteğine bağlı olsa da çok büyük oranla belirli bir zorunluluk sonucu gerçekleşir. Marshall (2003, s. 685) göç olgusunu; "Bireylerin ya da grupların sembolik veya siyasal sınırların ötesine, yeni yerleşim alanlarına ve toplumlara doğru kalıcı hareket içeren bir davranış" şeklinde; Yıldırım (2017, s. 228) ise, "sosyolojik açıdan ekonomik, toplumsal veya siyasi sebeplerle bir yerleşim yerinden başka bir yerleşim yerine gitme işi” olarak tanımlar. İsteğe bağlı göç genelde eğitim alma, iyi bir kariyer yapma, akraba ve aynı kültürdeki insanlarla beraber olma, ticaret yapma gibi gerekçelerden dolayı gerçekleşir. Zorunlu göçler ile bireylerin yaşantılarındaki sorunların çözümü neredeyse imkânsız hale gelmesi durumunda karşılaşılır. Kişinin vatanından sürgün edilmesi, iltica sonucu mülteci veya savaş mağduru olması gibi gerekçeler bunlar arasında sayılır.

Tarihin dönüm noktalarını oluşturan ve yine tarihe yön veren olayların en önemlilerinden biri de yaşanan savaşlardır. Tarihsel süreçte ve farklı coğrafyalarda neredeyse savaşın olmadığı bir döneme rastlamak belki de pek mümkün görünmez. Göç unsurunun gerçekleşmesine yönelik sıralamış olduğumuz gerekçeler içerisinde en yıkıcı olanlardan biri de savaştır. Savaş tanımlarından biri, "ülkeler, halklar veya kabileler arası silahlı ihtilaf” (Wahrig, 1992, s. 793) olarak verilir. Savaşların gerekçeleri kimi zaman ekonomik, kimi zaman siyasal veya kültürel, kimi zaman ise dini anlaşmazlıklar biçiminde sıralanır. Savaş kaynaklı göçler sonucunda kurulu bir düzeni olan ailelerin parçalandığı, sevenlerin ayrıldığı, aile bireylerinin sonsuza kadar yok oldukları görülür.

\section{AMAÇ}

$\mathrm{Bu}$ çalışmanın amacı Nur İçözü ve Canan Tan'ın bellek romanlarında göç olgusunun toplum ve bireyler üzerinde yıkıcı etkisini göstermektir. Yakın tarihimizde gerçekleşen Balkan Savaşları ile Kurtuluş Savaşı çerçevesinde konulaştırılan romanlardaki göç olgusu ile yerlerinden zorla edilen aileler ve bu ailelerin yaşadıkları trajik kaderleri karşılaştırılmaktadır. Bu karşılaştırma ile bireylerin veya ailelerin etnik kökenlerinden dolayı dışlanmaları, birbirini seven aşıkların aşklarına kavuşamamaları, göç edenlerin yabancılaşması, 
aşıkların yalnızlık çekip obsesyon geliştirmeleri gibi konu başlıklarını incelemek diğer amaçlar arasındadır.

\section{YÖNTEM}

Her iki eserin içeriği, yazarların yakın tanıdıklarının yaşantıları ele alınarak gerçeğe dayalı yazılmış bellek eserlerdir. Bu araştırmada ele alınan eserlerde ortak konu olarak göç, aşk ve travma izleklerinin etkileri incelenmiştir. Yöntemimiz karşılaştırmalı yazın bilimin inceleme yöntemlerinden biri olan metne bağlı inceleme (alm. Werkimmanent) (Aytaç, 2016, s. 104) ile yazınsal eseri öz ve biçim bakımı ile yorumlayıcı incelemedir (alm. Hermeneutik) (Aytaç, 2016, s. 106). Ayrıca nitel araştırma yöntemlerinden olan doküman incelemesi kullanılarak yapıtlar değerlendirilip göç, aşk ve travma izlekleri bilişsel ve duygusal işlevler açısından örnekler verilerek açıklanıp anlatımlar bu biçimde belirlenmiştir. Çalışmada, toplumsal davranış, yapı, işleyiş ve değerler gibi ögelerin analizini de yansıtan ve nitel incelemenin desenlerinden olan kültür analizi (Yıldırım vd. 2016, s. 67) üzerinde de durulmuştur.

\section{BELLEK}

\subsection{Jan Assmann ve Kültürel Bellek}

Bir diğer adı anlam aktarımı biçiminde belirlenen "kültürel bellek" ile insan belleğinin dış boyutu kastedilir [...] yani dış koşullar, toplumsal ve kültürel çerçevenin koşulları kültürel belleği oluşturur [...] kültürel belleğin oluşması ise yazının bulunması ile söz konusu olur [...] Yazı sayesinde kaydedilen haber ve bilgiler canlanıp beklenmedik ölçüde yaygınlaşma sağlarlar (Assmann, 1997, s. 25-28). Yukarıda da değinildiği gibi kültürel bellek daha çok yazınsal eserlerin aracılığg ile günümüze aktarılır.

\subsection{Maurice Halbwachs’a Göre Geçmişin Sosyal Yapısı}

Fransız sosyolog Maurice Halbwachs özellikle bellek konusu üzerinde yapmış olduğu çalışmalar ve ileri sürmüş olduğu fikirlerle belleği bireysel ve toplumsal olarak değerlendirir. Halbwachs'in temel düşüncesi belleğin sosyal koşullara bağlı olduğunu gösterir. Yani bir şeyler iyi veya kötü hatırlanacaksa bu olaylar belirli bir zaman ve mekân dâhilinde sosyal koşullar içerisinde yaşanmış ve belirli bir dönemin toplumunu etkilemiş olmalıdır. Assmann'ın (1997, s. 40-47) Halbwachs'tan yapmış olduğu bireysel ve toplumsal bellek kavramına yönelik alıntıda; belleğin insanın sosyalizasyon sürecinde oluştuğunu, belleğin bireysel olmasına rağmen toplumsal olduğunu, en kişisel anıların bile sadece sosyal grupların iletişimi ve etkileşimi üzerinden oluşacağını ve başkalarının anlattıkları, anlamlı diye vurguladıkları ve 
yansıttıklarını da hatırlayacağımızı [...] sadece ortak ve belirli bir gruba özgü "somut kimlikli" belleğin olacağını, bunun da zaman ve mekânla sınırlı bir gruba ait olacağını vurgular. Halbwachs ayrıca toplumsal anımsama için söylenmiş olan bir şeyin hatırlanması, okunan bir yazı veya çizilen bir tablo ve resmin bile yeterli olacağını belirtir (Erll, 2005, s. 141)

\subsection{Toplumsal Anımsamada İletişim Aracı Olarak Yazınsal Eserler ve Bellek}

Toplumsal anımsamaya kütüphane, müze, sanat anıtı gibi mekân ve yerler ile tablo, fotoğraf, film gibi iletişim ve yayın araçlarının yanı sıra sosyal bilimlerin bir dalı olan edebiyat da yazılı olması açısından son derece katkı sağlar. Yazınsal eserler insanların duygu ve düşünce boyutunu ortaya koyar. Farklı metin türlerinden oluşan yazınsal eserler, kimi zaman okuru bilgilendirmeyi, kimi zaman geçmiş ve geleneklere bir köprü kurmay1, kimi zaman ise rol model oluşturarak belirli yaş grubundaki bireylere yaşantı kazandırma isteğini amaçlar. $\mathrm{Bu}$ amacının yanı sıra okurda estetik kazanımı ve dilsel beceri zenginliğinin oluşumuna katkı sağlar. Yazınsal eserler, psikoloji, din, sosyoloji, tarih, felsefe vs. gibi disiplinleri de içererek birçok konuda metinler türettiği için ister gerçek ister ise kurgusal olsun kendisine anımsama alanında da yer edinir. Yazınsal eserler toplumsal olayları da farklı açılardan irdelediği için toplumsal bellek oluşumuna katk1 sunar. Böylelikle anımsama edebiyatı olarak adlandırdığımız bu edebiyat kuramının en önemli oluşum dayanağı öykülemedir. Erll'e (2005, s. 145-147) göre öyküleme süreçleri roman, nuvel, balad gibi yazınsal metin türleri ile sağlanır [...] özellikle gelişim romanı, tarihsel roman ve macera romanlarının yanı sıra seyahatnameler de toplumsal bellek ve anımsama kültüründe önemli yer edinir.

Halbwachs ve Assmann'in toplumsal bellek kavramlarından yola çıkılarak irdelenen eserlerde toplumsal olayların temelini yaşanılan dönemde gerçekleşmiş olan savaşlar oluşturur. Eserlerde toplumsal anımsama bakımından savaşın ne denli gereksiz olduğu, dönüşü olmayan bir yola girildiği ve insanlarda onarılmaz travmalar bıraktığ eleştirilmektedir. İncelenen eserleri daha iyi analiz edebilmek açısından 1900'lü yılların başında Osmanlı İmparatorluğu'nun etnik yapısına ve toprak bütünlüğüne kısaca değinilmelidir.

\section{OSMANLI IMPARATORLUĞU DÖNEMINDE FARKLI HALKLARIN BİR ARADA YAŞAMASI}

Osmanlı Devleti'nin 1299 y1lında kurulup 1922 y1lında ortadan kalkmasına kadar geçen süre içerisinde nice halklara ev sahipliği yaptığı bilinir. Osmanlı İmparatorluğu bu süreç içerisinde 
Anadolu'nun yanı sıra Asya, Avrupa ve Afrika olmak üzere üç kıtaya yayılarak dünya tarihinde kurulan en büyük imparatorluklar arasında yer alır. Bunca toprağa hükmeden Osmanlı aynı zamanda birden fazla milletin de sorunsuzca bir arada yaşamasına olanak sağlar. Osmanlı'da yaşayan farklı millet ve azınlıkların hangi şartlar altında hayatlarını sürdürdüklerini kimi zaman nesnel kimi zaman ise öznel bir bakış açısıyla belgeleyen kişiler elçiler ve seyyahlardır. Avrupalı elçi ve seyyahlar yazmış oldukları rapor, mektup veya seyahatnameler ile Anadolu'yu gezerken Osmanlı topraklarında yaşayan farklı etnik kökene sahip halkların olduğunu ve bu halkların nasıl huzur içerisinde bir arada yaşıyor olmasından bahseder. Bu bağlamda 1893 yılında İstanbul'dan Mardin'e kadar altı aylık bir seyahat sürdüren Dr. Edmund Naumann, özellikle İstanbul'un 1900'lü yılların başına doğru gelindiğinde sahip olduğu etnik yapıdan şöyle bahseder:

“Avrupa'nın ve ön Asya'nın her yerinden, hatta kuzey Afrika'dan bile insanlar farklı yapıda, giyimde ve gelenekte olmak üzere bu şehre gelmelerinden dolayı fiili olarak böyle bir ismin verilmesini hak etmektedir. Nüfusun ana yapısını Türkler, Yunanlılar ve Ermeniler oluşturmaktadır. Bunları ise Bulgarlar, eski Venedikli ve Cenevizlilerin son nesli olan ve Perot olarak adlandırılan İspanyol Yahudileri, Arnavutlar, Yugoslav Karadağlılar, Hırvatlar, Ulahlar, Sırplar, Çingeneler, Dürziler, Kürtler, Çerkezler, İranlılar, Gürcüler, Araplar, Sudanlılar ve diğer başka sayısız ırkların temsilcileri takip etmektedir" (Naumann, 1893, s. 11-12).

$\mathrm{Bu}$ aktarım ile Osmanlı İmparatorluğu'nda farklı halkların bir arada ve huzur içinde yaşadıkları görülür. Ancak 1900'lü yılların başında savaşların hız kazandığı ve her halkın bağımsız olma arzusu milliyetçilik düşüncelerine ivme katar, söz konusu halklar Osmanlı İmparatorluğuna karşı isyan ederler.

\section{SAVASSLARI VE ARDINDAN GELEN ANTLAŞMALARI DEVLETLER YAPAR BEDELINI HALK ÖDER}

Eserlerin anlatım zamanı iki farklı savaş dönemini kapsar. Nur İçözü’nün "Hürriyet" adlı eserindeki "Hürriyet" ana karakteri ve ailesi Selanik’ten Anadolu'ya göç ederken Balkan Savaşları; Canan Tan'ın "Hasret" adlı eserinin ana karakterlerinden Tacettin'in nikâhsız eşi "Patricia, oğlu Ali ve kayınvalidesi Omorfia'nın" Anadolu'dan tersine Selanik'e yapmış oldukları göç esnasında Birinci Dünya Savaşı ve onu müteakiben Kurtuluş Savaşı gerçekleşir. Her ne kadar da savaşların sonunda devletler kendi aralarında barış antlaşmaları imzalasa dahi antlaşmaları devletler yapar fakat bedelini halk öder düsturundan yola çıkarak savaş sonrası sivil halk mağduriyet ve travma yaşar. Bu bağlamda hem Balkan hem de Birinci Dünya Savaşı ile Kurtuluş Savaşlarını hatırlamak gerekir. 


\subsection{Balkan Savaşları}

Farklı nedenlerden dolayı gerçekleşen Balkan Savaşları, Birinci Balkan ve İkinci Balkan savaşları olarak ikiye ayrılır. Boray (2010, s. 245) Birinci (1912) ve İkinci Balkan Savaşları (1913) sonucunda Osmanlı'nın Türk tarihinde binlerce şehit ve yaralı vermesinin yanı sıra, yine Osmanlı'nın 500 yıldır sahip olduğu güney Avrupa topraklarının kilometrelerce karesini kaybettiğini, on binlerce Türkün Anadolu'ya göç etmek zorunda kaldığını belirtir. Yine Boray (2010, s. 223-225) "bu dönemi "PAN" hareketi, yani coğrafi bölge ve dil grubu, milli irk veya din itibarıyla birleşmeyi hedefleyen toplumsal hareket olarak tanımlar [...] Rusya'nın desteği ile Slav kökenlilerin bir araya gelebilmesi için Pan Slavizm ortaya çıkmıştır. Batılı tarihçiler genel anlamıyla bu türdeki halka dönük anarşik hareketler gösteren toplumsal çalışmalara daha çok milliyetçilik öncesi milliyetçilik denemesi adını verir."

Yıldırım (2006, s. 147), 1897 Türk-Yunan Savaşı nedeniyle göçmen açısından asıl darbenin Balkanlar'daki Müslüman nüfusa vurulduğunu, Balkan Savaşları ve Birinci Dünya Savaşı arasında geçen sürede Batı Trakya ve Makedonya'dan İstanbul'a ve Anadolu'ya göç edenlerin sayısını 413.000 ile 640.000 arasında olduğunu savlar. İşte bu savaşların en sıkıntılı döneminde Hürriyet ve ailesi Selanik’ten Anadolu'ya göç etmek zorunda kalır.

\subsection{Mübadele}

Eski dilde değiş tokuş (Püsküllüoğlu, 1997, s. 753) anlamına gelen mübadele kelimesi bu çalışmada genel ifade ile zorunlu nüfus değişimi olarak anlaşılır. Zorunlu nüfus değişimi birçok coğrafyada ağırlıklı olarak silahlı mücadelenin sonucunda meydana gelen kitlesel halk göçleridir. Kurtuluş Savaşı sonrasında Lozan Antlaşmasına göre halklar arasında nüfus mübadelesi yapılması gerekliliğini ileri süren kişi ise Norveç asıllı Dr. Fridtjof Wedel-Jarlsberg Nansen olmuştur. Yıldırım (2006, s. 75-76), Nansen'in adının neredeyse Türk-Rum mübadelesi ile özdeş bir hale geldiğini belirtir [...] Türk- Rum nüfus mübadelesinden önce Osmanlı hükümetinin Bulgaristan'la 15 Kasım 1913 tarihinde nüfus mübadelesi antlaşması ile Bulgaristan bölgesindeki 48.570 Müslüman ile Doğu Trakya'dan 46.764 Bulgar'ın mübadelesi gerçekleşir.

\subsubsection{Kurtuluş Savaşı Sonucunda Lozan Antlaşmasına (Lozan Sulh Muahedenamesi) Göre Türk-Rum Nüfus Mübadelesi}

Birinci Dünya Savaşı'nın sonunda Osmanlı Devleti savaşta birlikte hareket etmiş olduğu ülkelerle beraber yenik sayılır. Savaşın 
hemen sonrasında Milletler Cemiyeti Dr. Fridtjof Nansen'i mültecilerin durumu ile ilgilenmesi koşuluyla bölgeye atar. Osmanlı Devleti çok fazla askeri ve sivil kayıplara uğrar. Savaş sonrası yapılan antlaşmalardan biri olan 1918 tarihli Mondros Ateşkes hükümlerine uymayan düşman kuvvetleri zor durumdaki Osmanlı Devleti'nin zaafından faydalanmak istercesine Adana, Urfa, Antep, Antalya, Konya olmak üzere birçok ili işgal eder. Bu illeri işgal eden İtalyanlar 17.400, Fransizlar 49.000 ve İngilizler 41.500 asker ile yurdu talan eder (Tarih IV, 1934, s. 30). Osmanliya gelenek, görenek, anane ve dil bakımından bir İngiliz, Fransız veya İtalyan'a oranla bir Rum kökenlinin yaşam tarzı çok daha yakındır. Yüzyıllardan beri Osmanlı'nın birçok şehrine yerleşmiş olan Rum kökenliler yaşadıkları yerlerde Osmanlılar ile birlikte aynı sevinci paylaşmış aynı kederde hüzünlenmiştir.

Anadolu topraklarındaki insanların Rumlara karşı bu kadar saygılı ve hoşgörülü olması Yunan ordusunun 15 Mayıs 1919 da İzmir'e çıkması ile son bulur. Diğer yabancı ülkelerin yanı sıra Yunanlıların da Osmanlı topraklarına göz koyması kabul edilemez ve yabancıların işgalinden kurtulabilmek için Mustafa Kemal Atatürk önderliğinde başlayan Kurtuluş Savaşı zafer ile sonlanır. Savaş sonrası Mudanya Ateşkesi ve Lozan Antlaşması'yla yeni Türk Devleti varlığını tanıtır. (Tarih IV, 1934, s. 131)

Kurtuluş Savaşı sonrası gerçekleşen ve 21 Kasım 1922'den 24 Temmuz 1923 tarihine kadar süren Lozan Konferansı yeni kurulan Türk Devletinin kendisini müttefiklere kabul ettirme antlaşmasıdır. Bu antlaşma üzerinde müzakereler devam ederken konferans sürecinin bir bölümünde ve antlaşma henüz tamamlanmadan Yunanistan ile Türkiye arasındaki meselelere çözüm bulmak amacı ile 30 Ocak 1923 tarihinde Türk- Rum nüfus mübadelesi sözleşmesi devreye girer (Tarih IV, 1934, s. 125). Artık herkes kendi "anavatanına" dönmek zorundadır. Yıldırım (2006, s.148), savaş esnasında batıdan göçenlerle Anadolu içinde iç göç yaşayanların 900.000 civarında olmasının yanı sıra doğudan yani örneğin Azerbaycan'dan, Ermenistan ve Gürcistan'dan yaklaşık olarak toplam 243.000 civarında muhacirin Anadolu'ya göç ettiklerini bildirir.

\section{ESERLERIN OLAY ÖRGÜLERI}

Her iki eserde anıya dayalı olgu kuruluşu içerisinde ele alınmıştır. Anıya dayalı olgu kuruluşu içerisinde yazılan romanda, romanın barındırdığı kurmaca yapı, kronolojik bakımdan genellikle ileriye doğru bir seyir izler. Anlatıcının içeriği aktarma zamanı da çoğunlukla olaylar zincirinin bitişinden sonraki bir kesitte yer alır. Yaşananlar 
$\begin{array}{cc}\text { ÇÜTAD } & \text { Canan Tan ve Nur İçözü'nün Bellek Romanlarında } \\ \text { Haziran 2021 } & \text { Göç ve Aşk Mübadelesi Üzerine Bir Karş1laştırma }\end{array}$

biter, geçmişte kalır; sıra bu yaşantı dizisini anlatmaya gelir. Anlatılan yaşantı akışı geriye dönüş tekniği (Sazyek, 2013, s. 23) ile aktarılır.

\section{1. "Hürriyet” Bir Sevda Masalı}

Selanik'te yaşamakta olan Ahmet Asım Bey ve ailesi Balkan Savașları'nın sonlarına doğru savaștan etkilenen ve zorunlu göçe maruz kalan binlerce aileden biridir. Silah ticareti yapan Ahmet Asım Bey, ailesi ile birlikte son derece varlıklı bir yaşam sürer. 1912 yılının ortasında ve de Balkan Savaşlarının cereyan ettiği bir dönemde Bulgar çeteleri Türk ve Müslüman ailelere saldırmaya başlar. Bu saldırılardan Ahmet Asım Bey ve ailesi de etkilenerek can güvenlikleri açısından yurtlarını terk etme mecburiyetine düşerler. Ahmet Asım Bey ve eşi Rabia Hanım çuvallar dolusu altın, mücevher ve değerli eşyalarını bir gecede arkalarında bırakarak sadece Muvaffak, İradet ve Hürriyet adlı üç çocuklarını yanlarına alıp göç etmek zorunda kalır. SerezSelanik'ten hareket eden aile uzun çabalar sonucunda İstanbul'a ulaşır. $\mathrm{Bu}$ göç, ailenin ilk göçü olarak kabul edilmelidir. Zira söz konusu aile bundan sonraki göçlerini Anadolu'nun farklı illerine iç göç olarak gerçekleştirir. Artık Ahmet Asım Bey ve ailesi gibi binlerce aile kafileler halinde doğup büyüdükleri yerleri terk eder. Göçün yaratmış olduğu olumsuz şartlara daha fazla dayanamayan ailenin en küçük çocuğu İradet seyahat esnasında ateşlenip hastalanır ve birkaç gün sonra vefat eder. Ahmet Asım ve ailesi böylelikle ilk acıları ile karşılaşmış olurlar.

Aile, İstanbul'a geldikten sonra kendilerini geçindirebilecek bir iş bulabilme amaciyla önce Manisa'ya daha sonra sırasıyla Giresun, İzmir, Isparta ve Adana'ya göç eder. İstanbul'da kaldıkları müddet içerisinde Hürriyet'in abisi Muvaffak hukuk fakültesinde okumaya başlar. Günün birinde sınıf arkadaşı İsmail'i eve davet eder. İsmail ile karşılaşan 15 yaşındaki Hürriyet'in aşkı alevlenip sonsuzlaşır. Hürriyet, gelecekteki mutlu günlerin hayalini kurarken, İsmail'in ailesi Hürriyet'i gelinleri olarak kabullenmek istemez. Oğullarını evlendirmek için başka bir kız istedikleri gün aşkına kavuşamayacağını anlayan İsmail, Hürriyet ve Hürriyet'in babasına vermiş olduğu sözü tutamamanın utancı ile intihar eder. Hürriyet bu travmayı atlatamaz ve saplantılı bir hayat sürmeye başlar. Hürriyet yıllar sonra kendisinden yaşça küçük olan Ahmet adlı bir gence kaçar. Bu sefer de Ahmet'in ailesi ve özellikle de kayınvalidesi tarafından kabul görmez, sefalet içinde yaşar ama öleceği güne kadar kalbi kavuşamadığı ilk aşkı İsmail için çarpar. 


\subsection{Hasret}

Hasret adlı eser tıpkı Hürriyet adlı eser gibi anıya dayalı olgu kuruluşu içerisinde anlatılan bir romandır. Romanımızın konusu Ankara'nın Keskin ilçesinde başlayan, zaman açısından Kurtuluş Savaşı ve Cumhuriyet öncesi dönemde yaşanan ve birbirlerine kavuşamayan âşıkların ölümsüz aşklarıdır. Eser kahramanları Cerid Aşiret Beyi Hacı Ali Bey'in oğlu Tacettin ile meyhane işleten Rum asıllı Omorfia'nın kızı Patricia'dır. Tacettin, Patricia'yı görür görmez âşı olur. Ancak dönemin sosyolojik ve kültürel yapısı Müslüman bir genç ile Gayrimüslim bir kızın birlikte olmasını, hatta evlenmesini asla kabul etmez. Tacettin aşkını gizlice yaşamak zorundadır.

$\mathrm{Bu}$ aşkın meyvesi olarak oğulları Ali dünyaya gelir. Dünyaya gelen torunları dahi Tacettin'in anne ve babasının yüreğini yumuşatamaz. Kurtuluş Savaşı sırasında Yunanistan'ın İzmir'i işgal etmesi Keskin'de Rumlara farklı bir gözle bakılmasına neden olur. 1923 yılına gelindiğinde Lozan Barış Antlaşması ile Türk topraklarına yerleşmiş olan Rum Ortodokslar ile Yunan topraklarına yerleşmiş olan Müslüman Türklerin zorunlu mübadelesine başlanır. Tacettin her ne kadar da ailesini ikna etmeye gayret gösterse de onlara Patricia'yı gelinleri olarak kabul ettiremez. Omorfia, Patricia ve Ali zorlu bir yolculuk sonucu doğup büyüdükleri topraklardan ayrılarak Selanik'e varır ve oraya yerleşirler. Tacettin ise saplantılı bir biçimde aşkını yüreğine gömüp yaşamaya devam eder. Yıllar sonra başka bir kadın ile evlenir, bir kızı ve bir oğlu olur. İkinci Dünya Savaşı yıllarında Yunan askeri olarak savaşıp yaralanan Ali, Tacettin'in eski bir arkadaşı tarafından tanınır ve böylelikle Ali'ye tüm gerçekler anlatılır. Savaştan sonra gün gelir Ali'nin yolu artık emekli olmuş babası Tacettin'i görmek için Keskin'e düşer. Tacettin ağlayarak oğluna neler yaşandığını anlatır ve Patricia'ya hala âşı olduğunu söylemesini Ali'ye tembihler. Tekrar ne zaman görüşecekleri ise meçhuldür.

\section{ESERLERDE KARŞILAŞTIRILAN IZLEKLER}

\subsection{Göç Yolları}

Eserlerdeki ilk karşılaştırma, eser kahramanlarının yapmış oldukları göç güzergâhı açısından değerlendirilir. Hürriyet'in ailesi Birinci Balkan Savaşı döneminde Selanik'ten günümüz Türkiye'sine göç eder, Tacettin'in nikâhsız eşi Patricia, oğlu Ali ve kayınvalidesi Omorfia, Lozan antlaşması (1923) ile gerçekleşen mübadele sonucunda Türkiye'den Selanik'e yol alır. Böylelikle her iki eserin göç güzergâhı birbirlerinin ters istikametindedir. Hürriyet ve ailesinin Serez'den ayrılmalarının haklı sebepleri vardır. Eserde toplumsal yaşantı şöyle aktarılmaktadır: 
Serez'de yaşam giderek işkenceye dönüşüyordu. İşgalin daha ilk günlerinde asıl hedefin Türkler olduğu anlaşılmıştı. Konağa yeni bir katliam haberinin gelmediği gün yok gibiydi. Bulgar komitacıların ve askerlerinin ilk işi, camilerden birkaçının minaresini yıkarak kiliseye çevirmek olmuştu. Kentlerde sarkıntılık, tecavüz olayları her geçen gün artıyordu [...] Korkulan baskın bir gece yarısı gerçekleşti [...] Yorgo, Ahmet Asım Bey'e Bulgar çetelerin baskın yapacağını bildirdi [...] Ahmet Asım Bey ve ailesi onca zenginlik ve altınları geride bırakarak sebep ne olursa olsun, bu göçe yalnızca belindeki kesede kalan birkaç altın ve paltosunun cebindeki bir avuç gümüş mecidiyeyle çıkıyordu (İçözü, 2012, s. 59- 66).

Göçün tersi bu sefer Patricia için geçerli olacaktır. Yunan ordusunun İzmir'e çıkması Osmanlı topraklarının her karışında olduğu gibi Keskin beldesinde de infial yaratır. Bu durum Rumlara karşı farklı gözle bakılmasını sağlar. Yunanlılar sadece İzmir'i işgal etmekle kalmaz, Anadolu'nun içlerine doğru ilerleyerek neredeyse Kütahya'ya varırlar. Keskin'e ulaşan her kötü haber yıllarca kardeş gibi yaşayan Rum ve Türkleri karșı karşıya getirmeye yeter de artar bile.

“Huzursuzdu insanlar. Türk’ü, Rum’u, Ermeni’si, tüm Keskinli umutsuzdu, öfkeliydi, kırılgandı. Eski günler geride kalmıș gibiydi. Kuşkuyla, endişeyle bakıyorlardı birbirlerine. Türkler, memleketi işgal edenlerle aynı kanı taşıdıkları için azınlıklara kinleniyor, İzmir'de Türk tabiiyetindeki bazı Rum gençlerinin Yunan ordusuna katıldığı haberlerine isyan ediyorlardı" (Tan, 2013, s. 72).

Azınlıkta kalan Rumlardan alıșveriș yapılmıyor, Yunan askerlerinin yaptıklarının hesabı adeta Keskin'de yaşayanlardan sorulur olmaya başlanır. Asırlardır bilinen beraber yaşama ve dayanışma dengeleri bozulur. Mustafa Kemal Atatürk ve ordusu düşmanları yendikçe Anadolu'da bayram havaları esmeye başlar ve Yunanlılar yenildikçe Keskin'deki sosyal yaşam değişime uğrar.

"Tacettin kazanılan zaferlerle delicesine seviniyor, ancak çevresindeki Rumların, özellikle de Patricia ve Aris'in çaresiz çırpınışlarına da aynı derecede üzülüyordu. Patricia, Yunan askerleri için, "Yerimizi dar ettiler" diyor, "Buralardan sürülmemiz yakındır" diye korkularını dile getiriyordu. "Kimseler yüzümüze bakmıyor vre Tacettin" diye sılanıyordu Aris. "Bu gidişle seninle de yollarımızı ayırmak zorunda kalacağız” (Tan, 2013, s. 91-92).

Keskin'de veya Anadolu'nun diğer illerinde düşmanların yenilip yurdumuzdan kovulmaları elbette Türk halkına sonsuz mutluluk verir. Ancak uluslararası hukukun getirmiş olduğu birtakım sorumluluklar da Anadolu insanının omuzuna yük olur. Lozan antlaşması ile devreye giren Türk- Rum mübadele sözleşmesi Tacettin ve Patricia için yeni 
bir dönüm noktasıdır. Savaşın bittiğine ve artık her şeyin eskisi gibi olacağına hatta kendilerini daha güzel günlerin geleceğine inandıran Tacettin, mübadele sözleşmesinin getirmiş olduğu yükümlülüklerin karşısında çaresizdir. Sözleşmenin henüz 1. maddesi Tacettin'in hayallerini yıkar. Bu madde; Türk topraklarında yerleşmiş Rum Ortodoks dininden Türk uyruklarıyla Yunan topraklarında yerleşmiş Müslüman dininden Yunan uyruklarının 1 Mayıs 1923 tarihinden başlayarak, zorunlu mübadelesine (Exchange obligatoire) girişilecektir. $\mathrm{Bu}$ kimselerden hiçbiri, Türk Hükümeti'nin izni olmadıkça Türkiye'ye ya da Yunan Hükümeti'nin izni olmadan Yunanistan'a dönerek orada yerleşemeyecektir" (Tan, 2013, s. 98) ifadesini taşımaktadır. Böylelikle mübadele edilen Rumların ve Türklerin her ne suretle olursa olsun tekrar eski yerlerine yerleşmeleri yasaklanır. Artık Patricia ve Tacettin için "göçün tek yönlü bir yolculuk olduğu ve geri dönülecek bir "yuva"nın olmadığı" gerçeği" (Hall, 1987, s. 44) ile yüzleşmeleri kaçınılmazdır. "Omorfia son kez treni beklerken çıplak ayakla memleket toprağına bastı [...] çok iyi biliyordu ki, yaşadığı o anın asla tekrarı olmayacaktı (Tan, 2013, s. 140). Göçenler asla geri dönemeyecekler, gittikleri yerde ise ne "buralı" ne de "oralı" olamayacaklardır. Patricia ile oğlu Ali, Tacettin'in elinden kayıp gider, gösterdiği bütün gayretler boşa çıkar.

\subsection{Göç ile Yaşanan Maddi ve Manevi Kayıplar ve Buna Bağlı Gelişen Yas}

Bir bilinmeyene doğru zorunlu göç eden insanların manevi kayıplarının yanı sıra en önemli kayıpları da maddi varlıklarıdır. Hürriyet, manevi kayıp olarak arkasında kardeşi İradet ve sevdiği olan İsmail'i, Omorfia ise rahmetli kocası Dimitri'yi Anadolu topraklarında bırakır. Maddi kayıplar ise yıllarca emek harcanan mal ve mülkün yok pahasına elden çıkarılması biçimindedir. Hürriyet'in babası Ahmet Arif Bey güzelim köşkünü öylece bırakıp giderken, Omorfia tavernasını değerinin çok altında devreder. Hem Hürriyet hem de Tacettin kendi canlarından çok sevdiklerini sonsuza kadar kaybeder, kendi iç dünyalarına kapanır ve adeta yasa bürünürler. Schmitt ve Mees (2000, s. 209) yas kavramını, bir kişinin veya birden fazla kişinin kendisine çok yakın hissettiği birini veya birilerini ağır veya geri dönülemez bir biçimde kaybetmesi veya vazgeçilmesi gereken önemli yaşam hedeflerinin, sosyal rollerin veya sahip olunan maddi şeylerin kaybı sonucunda göstermiş olduğu acı dolu tepkisi [...] Yasta olmayı ise, bezginlik, bir şeye katılım sağlamama, sosyal ortamlardan çekilme, yıkılmışlık duygusu gibi belirtiler vasıtasıyla ortaya çıkan durum olarak ifade ederler. Yaşamış oldukları bu yoğun üzüntü sonucu her iki eserin ana karakterlerinde belirli saplantıların oluşması kaçınılmaz olur. 


\subsection{Manevi Kayıplar Saplantıları Doğurur}

Eserlerdeki ana karakterler daha önceden de belirtildiği gibi aşklarına kavuşamazlar. Hürriyet'in sevgilisi olan İsmail intihar ederken, Tacettin'in nikâhsız eşi Patricia ve ondan doğan oğlu Ali Yunanistan'a göç eder. Her iki ana karakter aşklarına kavuşamamanın vermiş olduğu duygusal acının sonucunda aşklarına karşın obsesif davranışlar geliştirir. Yaşadıkları bunalımların sonucunda saplantılı birer hayat sürmeye başlarlar. Budak (2009, s. 630) saplantıyı, "istenmeyen, bunaltıcı olan ve bastırmaya, unutmaya yönelik çabalara rağmen istemsizce ve tekrar tekrar bilinç düzeyine sızarak kendini gösteren inatçı bir düşünce, dürtü veya imaj” olarak tanımlar. Hürriyet, yaşanan ve sonu neredeyse gelmeyecek gibi görünen bütün olumsuzlukların sonucunda hayatını monotonlaştırır ve sabahın ilk saatlerinden başlayıp akşama kadar her gün sadece ev temizliği yaparak sürekli aynı şarkıyı söyler.

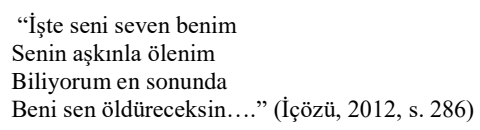

Hürriyet'in ağzından düşmeyen şarkı kendi özü olur, kendini hep bu şarkıda bulur. Her gün yapmış olduğu ve saatlerce süren temizlik takıntısı ile bir saplantı geliştirir. Hürriyet artık obsesif kompulsif bir durum yaşar. Hürriyet'in söylediği bu şarkı kendi zihninin monoloğu halini alır. Tacettin ise, Patricia ve Ali'yle bir fotoğraf çektirir ve ondan iki adet hazırlatır. Birini giderken Patricia'ya vermek ister ancak fotoğraflar zamanında hazırlanamadan Patricia, oğlu Ali ve kayınvalidesi Omorfia, Keskin ilçesini terk etmek zorunda kalırlar. İște Tacettin'in saplantısı veya obsesyonu bu fotoğrafların basılmasından sonra başlar.

"Tacettin ise iyice içine kapanmıştı. Gerek işte gerek evde gün boyunca ağzından çıkan kelime sayısı gitgide azalıyordu. Patricia'yla Ali'nin yanı sıra Aris'le Artin'i, onların dostluklarını da delice özlüyordu. Akşamları düzeni bozmamak için sofranın bir köşesine ilişiyor, iki üç lokma bir şeyler atıştırıp odasına çıkıyordu. Ancak orada çözülüyordu dili. Çekmeceden çıkardığı fotoğrafın karşısında gülüyordu yüzü. Saatlerce konuşuyordu Patricia'yla. Masallar anlatıyordu Ali'ye. Bakışlarıyla dokunarak okşuyordu ikisini de. Uykuya teslim olurken, göğsünde uyutuyordu onları da. Kimseler bilmiyordu ama, biricik saadeti buydu Tacettin'in...” (Tan, 2013, s. 201).

Böylelikle Tacettin'in saplantısı, her akşam yatağının başucundaki komedin çekmecesinden Patricia ve Ali'nin fotoğrafinı çıkarıp onlarla dertleşmek, onlara karşı yaptığı yanlışlarını itiraf 
etmekten ibaret olur. Eserlerdeki ana karakterlerden her biri "nesne kaybı" (Budak, 2009, s. 509) yani sevilen kişinin ölüm, hastalık, terk vb. gibi nedenlerle kaybedilmesini yaşarlar. Her iki ana karakter yaşamış oldukları ayrılık travmasından sonra hem toplum hem de aile içi ortamda kendilerini geri çeker adeta etraflarına birer koza örerler. Neredeyse dış dünyadan tamamen izole olur ve yalnızlığa itilirler. Psikolojik olarak da ayrılık ve yalnızlık çekerler. Bu bağlamda Freud, yas sürecinin dinamiklerini tanımlarken "yalnızlık yaşantısını kaybedilene duyulan özlem ve kendisini zamansız bırakıp gidene duyulan öfke olarak” dile getirir (Hilal, 2001, s. 40).

Freud'un bu ifadesinden yola çıkınca Tacettin'in elinden yitirdiği eşi ve oğluna özlem duyması ile Hürriyet'in kendisini zamansız bırakıp giden İsmail'e aslında özlemle beraber öfke duyuyor olması verilen tanımla birebir örtüşür. Hürriyet, her ne kadar bu öfkesinden ötürü kendisi de intihar etmeyi düşünse bile ailesine ve abisine karşı vermiş olduğu sözden dolayı bunu başaramaz. Gerçi bir defasında intihar etmeyi dener ancak başaramaz. Hürriyet iç monolog ile intihar etmek istediğini şöyle dile getirir.

\begin{abstract}
"Boğuluyorum! Boğuluyorum Allahım! Bu duvarlar beni boğuyor! Duvarlar üstüme üstüme geliyor! Ah İsmail! İsmail beni de niye yanında götürmedin? Hep anam yüzünden! Bitecekti bu iş, bitecekti geçende [...] Engel oldu. Cesaretim mi kalmadı? Var, hem de eskisinden de daha cesurum. Ama abim [...] yüreği yaralı abime kıyamam. İsmail'den bana kalan tek hatıra. Söz verdim ona! Bir daha böyle bir şey yapmayacağıma söz verdim. Yoksa çok kolay, Seyhan kimleri yutmamış ki beni almasın! Hemen şuracıkta. Bir koşu gittim mi herkes huzura erer. Ama söz verdim. Abime söz verdim [...] Canıma kıymayacağım” (İçözü, 2012, s. 308).
\end{abstract}

\title{
8.4. Göç Edenler Vardıkları Yerde Yabancılașır
}

Yabancılaşma kavramına göç olgusu açısından bakılırsa bunu bir bireyin hem yeni geldiği "çevreye" hem de "kendi kendine" yabancılaşması olarak değerlendirilir. Yabancılaşma kavramı Rousseau, Goethe, Fichte, Hegel gibi Fransız ve Alman düşünürleri tarafından ele alınmış ve üzerine düşünce yazıları yazılmış olmasına rağmen, yabancılaşma kavramının daha çok Yahudi asıllı Alman filozof Karl Marx'da vücut bulduğu görülür. Marx'ın yabancılaşma teorisi sosyolojik boyutu ile öz ve yabancı kavramları açısından yeni varılan yerde diğeri tarafından dıșlanmak biçiminde ele alınır (Marshall, 2003, s. 788). Dolayısıyla yukarıda da bahsedildiği gibi göç etmiş olan bireylerin doğup büyüdükleri çevreden belirli gerekçelerden ötürü istemeden ayrılmaları sonucunda yeni vardıkları yerde her açıdan yabancılaşırlar. 
İçözü ve Tan'ın eserlerinin farklı bölümlerinde özellikle sosyolojik ve psikolojik yabancılaşma örnekleri aşağıdaki alıntılarla karşılaştırılabilir. Hem İçözü’nün hem de Tan'ın eserinde anlatılan göçmen aileler, göç etmiş oldukları yerde ilk önceleri huzur bulamazlar. Yeni bir çevre, yeni bir yaşam ve hatta yeni insanlar yadırgar onları. $\mathrm{Bu}$ aileler, yeni vardıkları yerde yaşayanlarla aynı kökene tabii olsalar dahi bir müddet dışlanır ve hor görülürler. İçözü'nün eserindeki Hürriyet karakteri ailesi ile adeta iç göç yaşar. Hürriyet'in abisi memuriyeti dolayısıyla birçok yere tayin edilir. $\mathrm{O}$ neredeyse aile de oradadır artık. En son yerleştikleri il Adana'dır. Adana'da Hürriyet'in yolu daha sonra kaçıp evleneceği Ahmet ile kesişir. Hürriyet'in kaçtığı ve eşi olacak olan "Kontena" lakaplı Ahmet'in ailesi de Müslüman olmalarına rağmen Girit'ten göç ettikleri için belirli bir süre "gâvur" ithamı ile karşılaşır. Bu kaba ve alaycı ifade mahalledeki diğer komşuların çocukları tarafından söylenir Ahmet'e.

“Gavur tohumu,...Gavur...Gavur...Gavur Ahmet! Defol git! Gelme yanımıza!" [...] Ahmet, ilk defa o gün yabancı hissetmişti kendisini. Babası anavatan diyordu, oysa bilmediği topraklarda, bilmediği bir dili konuşan insanların arasında kendisini nasıl vatanında hissedebilirdi?" (İçözü, 2012, s. 269-271)

Aynı sıkıntıları Selanik'e vardıklarında kendileri gibi Rum olan mahalle sakinleri arasında Omorfia ve Patricia da yaşar. "Zaman her şeyin ilacıdır" [...] Omorfia ve ailesi yeni bir düzen kurar [...] Ama ne zorluklarla [...] Kendi kanlarından olan insanların aşağılamalarına maruz kalır, dışlanırlar. Anadolu'dan gelmiş, Türkçe konuşan, adetleri, tavirları hatta tipleri bile kendilerine benzemeyen bu yabancıları yadırgamıştı yerli ahali (Tan, 2013, s. 208-209).

Bu bağlamda her iki eserde de eser kahramanları kendi soydaşları tarafından yabancılaştırılırlar. Yabancılaşmaya verilebilecek bir diğer örnek ise Tacettin'in kendisine yabancılaşmasıdır. Patricia ve Omorfia Selanik'e gittikten sonra kimsenin yanında barınamayan Tacettin yalnız kalmıştır. "Tacettin evsizdi, barksızdı, gidecek yeri, sığınacak kimsesi yoktu” (Tan, 2013, s. 109).

\subsection{Aile ve Toplum Baskısından Kaynaklanan Mazideki Günahlar}

İnsanoğlu sosyolojik açıdan tek başına yaşayamayan, muhakkak bir toplum içerisinde hayatını sürdürmesi gereken bir varlıktır. Dolayısıyla içinde yaşadığı toplumun kurallarına uyma mecburiyeti doğar. Eserlerdeki ana karakterlerin geleneksel toplum tipinin içerisinde sıkıştıkları görülür. Doğan (2014, s. 94) geleneksel toplum tipini; "yüz yüze ilişkilerin egemen, toplumsal değerlerin ve 
alışkanlıkların baskın, akrabalıkların önemli, bireyin yerine toplum (cemaatin) menfaatlerinin önde olduğu" şeklinde tanımlar. Bu tür toplumlarda daha çok ailenin sözü geçerlidir. Eserlerde de aile adına sözü geçen karakterler anne ve hatta kayınvalidedir. Anne karakterleri toplumun yapısına göre davranır, gelenek ve göreneklere bağlı kalmayı tercih ederler. Fakat bu tercihlerinde çocuklarının hayat akıșını değiștirdiklerinin farkına varamazlar. Eserlerdeki anne sembolü, ana karakterlerin hayat seyirlerini ve kaderlerini belirleyen olur. $\mathrm{Bu}$ bağlamda öncelikle annelerin toplumdaki baskın gücünden bahsetmeden önce kadının toplumdaki yerinden bahsetmek gerekir.

\subsubsection{Kadın}

Kadın; semavi veya semavi olmayan dinlerde, mitolojide ve tarih boyunca ortaya çıkmış olan farklı uygarlık ve medeniyetlerde kutsallığı, üremeyi, dişiliği, hayatın sürmesini ve bereketi simgeleyerek saygı görür. Ancak saygı gördüğü kadar, değişen toplumsal yapılara göre erkeğe bağlı kılınır, yerine göre horlanır, ezilir, cinsiyet ayrımına, baskıya ve acıya maruz kalır. Kadına bu denli olumsuzlukları sadece erkeklerin değil kendi hemcinsleri olan başka kadınların da yaşattıkları bilinen bir gerçektir. Bu denli ruhsal çöküntüleri yaşatanlar kadının bizzat kendi annesi, kayınvalidesi veya kız kardeşidir.

\subsubsection{Bazı Günahları Çocuklarını Çok Sevdiklerini Söyleyen Anneler İşler}

\subsubsection{Anne}

İnsanoğlunun doğurgan cinsi olan kadının bedeninde yeni bir can taşıyarak kendisinden bir parçayı dünyaya getirmesinden sonra en kutsal varlıklar arasına girerek "anne" sıfatını kazanması, her toplumda saygı ile karşılaşılan bir durumdur. Temel anlamda "çocuğu olan kadın" (Hançerlioğlu, 1986, s. 17) ile ifade edilebilen anne kavramı aynı zamanda "bütün bir yaşam, bereket, koruma, besleme ve toprak prensiplerini de sembolize" (Gardin vd. 2014, s. 38) eder. Butzer ve Jacob (2012, s. 284) yazınsal eserlerde karşımıza çıkan anne sembolünü; "yaşamın, doğurganlığın ve sevginin sembolü olmanın yanı sıra yıkım, tahribat ve ölümün de sembolüdür [...] olumlu bakış ile yaşamı başkasına aktaran, doyuran ve bakım sağlayan, affeden, çare bulan ve iyileştirendir [...] olumsuz bakış ile fiili veya manevi zehirleyen, kördüğüm eden, tahrip eden ve öldürendir" olarak tanımlarlar.

Türk toplumu açısından bakıldığında, anne sembolüne gösterilen hürmet sadece biyolojik anneye değil aynı zamanda ikinci bir anne 
statüsünde olan kayınvalideye de gösterilir. Şark ve Türk toplumlarında anneye olan saygı, değerler eğitimi sonucunun yanı sıra daha çok gelenek- göreneklerin yanı sıra İslamiyet inancının etkisi ile pekiştirilir. İslamiyet her firsatta anne ve babaya saygılı olmayı ve onlara itaat etmeyi vurgular. Kur'an- Kerim'in Lokman suresinin 14.15. ayetinde "Biz insana, ana-babasına iyi davranmasını tavsiye etmişizdir. Çünkü anası onu nice sıkıntılara katlanarak taşımıştır. Sütten ayrılması da iki yıl içinde olur. (İşte bunun için) önce bana, sonra da ana-babana şükret diye tavsiyede bulunmuşuzdur" ifadesi annelerin İslam inancı açısından kutsallığını ortaya koyar. Keza "Cennet anaların ayağının altındadır" ifadesi de annelerin ne denli kutsal olduğunu hatırlatır. Her iki eserde de ana karakterlerin sevdikleri insanları kabullenmek istemeyen, onları anlamakta zorlanan ve onlarla empati kuramayan kişiler annelerdir, diyesi kayınvalidedir. Ancak karşılaştırdığımız her iki eserde de mağdur duruma düşen kadın figürleri yaşadıkları veya yaşamak istedikleri aileler içerisinde destek bekledikleri diğer kadınlardan hiç de beklenilmeyen tutum ve davranışlar görürler.

\subsubsection{Hemcinslerin Düşmanlığı}

\subsection{Hürriyet'in Hayat Seyrini Değiştiren Pürüzat ve İfakat Hanımlar}

Yukarıda aktarılan ifadeler doğrultusunda Hürriyet'in hayat seyrini değiştiren iki kadın ile karşılaşılır. Bunlardan ilki İsmail'in annesi Pürüzat ve ikincisi ise kaçarak evlendiği Ahmet'in annesi yani Hürriyet'in kayınvalidesi İfakat Hanımdır. Pürüzat Hanım gönülsüzce de olsa Hürriyet'in ailesi ile tanışır. İlk ifadesi "Toy çocuk! Ailelerimiz arasındaki derin uçurumu görmek için, şu evlere bakmak bile yeterli" (İçözü, 2012, s. 178) biçimindedir.

Pürüzat Hanım daha sonra oğlu İsmail’i başka bir gelin adayı ile nişanlamak istemesi üzerine nişan günü İsmail intihar eder. İsmail'in intiharı Hürriyet'in de hayat akışını değiştirmiştir. Hürriyet, İsmail'in ölümünün üzerinden geçen birkaç yıl sonra Ahmet’e kaçarak onunla evlenir. Ancak bir kadının hemcinsi olan başka birine yaşatabileceği zorlukları Hürriyet bu sefer kayınvalidesi olan İfakat Hanım tarafından görür. Hürriyet kaçarak evlendiği Ahmet'ten altı yaş büyüktür. Bu bile İfakat Hanımı çileden çıkarmaya yetmişken, aynı etnik kökene mensup olmalarına rağmen İfakat Hanım Hürriyet'i dışlar. İfakat Hanım oğlu Ahmet'e;

"Olmaz!... Girit mahallesinde sana kı mı yok...Soylarını soplarını adetlerini biliriz...Ne demeye hiç tanımadığımız, 
bilmediğimiz insanlarla karşılaştırmaya çalışırsın bizi”? der (İçözü,

2012, s. 302)

Ancak İfakat Hanım Hürriyet ile oğlu Ahmet'in evlenmesini engelleyemez, fakat Hürriyet'e manevi ve fiziksel şiddete varan baskılar uygular.

"Gerdek sabahı fes renginde kadife elbisesiyle sofrada kocasının yanına diz çöktüğünü gördüğü anda cinleri yine tepesine çıktı. "Ooooh maşallah! Gelin aldık artık köşemize çekiliriz diyorduk, tam tersi, izzetüikram beklemekte hanımefendi! [...] Gelin hanım ne öyle misafir gibi oturmaktasın [...] hadi kalk şöyle bir dolanda, eve gelin aldığımızı anlayalım." (İçözü, 2012, s. 361).

\subsubsection{Tacettin'in Hayat Seyrini Değiştiren Fatiş Hatun}

Kadın dayanışmasını sonuna kadar hissetmek isteyen Patricia, Tacettin'in annesi Fatiş Hatun'dan kayınvalide yakınlığı göremez. Fatiş Hatun'un yaşadığı dönemdeki sosyal ortam anne otoritesini korumas1 gerektiğini gösterir. Kendine özgülüğü yaşayıp son sözü söyleyecek olan kişi olma isteği ile kendisi hakkında yaratmış olduğu bu imge, oğlu Tacettin'in mutluluğuna gölge düşürse de, toplum tarafından olumsuz yargılanmamak için katı tavrından vaz geçmez. Tacettin'in Patricia ile yaşamış olduğu tutkulu aşkın sonunda ismini Ali koyacağı bir oğlu olur. Yeni doğan bu çocuk ile kendi ailesi arasındaki dargınlığın son bulmasını ve Patricia'yı gelinleri olarak kabul etmelerini uman Tacettin, söz konusu güzel haberle baba evine varır.

"Hoş gelmişsin oğul! diyerek sessizliği bozdu Hacı Ali Bey [...] Bir oğlum oldu baba! dedi Tacettin [...] Hayırlı olsun evlat! diyebildi Hacı Ali Bey. Gözleri Fatiş Hatun'un üzerindeydi Tacettin'in. Cansız, ruhsuz, taştan bir heykelden farkı yoktu anasının [...] Sen de hayırlı olsun demeyecek misin anacığım? dedi. Fatiş Hatun'un asık suratı daha da ekşidi. Zehir gibi bir bakış firlattı Tacettin'e, başını hışımla ters yöne çevirdi. Yılmadı Tacettin, anasının elini tutmak için ani bir hamle yaptı. Fatiş Hatun ateşe değmiş gibi, sertçe geri çekti elini. "Günahsız bir sabi o" dedi Tacettin. Senin torunun! Ağlamaklıydı sesi. Tacettin'in yüzüne bile bakmadan, "Doğrudur" dedi Fatiş hatun. Hasbelkader torunum oldu. Evet, günahsız ve henüz tertemiz bir sabi. Söyleyeceğim odur ki, gavurların elinde daha fazla kirlenmeden ya onu buraya getirirsin..." Durdu soluklandı bir an. "Ya da" diye devam etti, benim Tacettin adında bir evladım yok der, bağrıma taş basarım" (Tan, 2013, s. 80-82).

Tacettin sevdiği kadını ailesine ve bilhassa annesine kabul ettirebilmek için her türlü yolu denese de annesi Fatiş Hatun'u inadından vaz geçiremez. Fatiş Hatun Patricia'yı gelin olarak kabul 
etmez. Yaşanan birtakım olaylar ve duygusal baskılar sonucu Tacettin en sonunda baba evine döner. Elbette buna en çok sevinen Fatiş Hatun olur.

\footnotetext{
“Fatiş Hatun'un etekleri zil çalıyordu sevincinden. Oğlu, Tacettin'i yuvasına dönmüştü sonunda. "Tıpış tıpış gelecek demedim mi sana ben? diyordu Ümüş Hatun'a. Geldi işte! Sira mürüvvetini görmekte. Helal süt emmiş, ailemize yaraşır bir kız bulduk mu o da olacak evelallah" (Tan, 2013, s. 200).
}

Fatiş Hatun, Ümüş Hatun'a kuma gelmiş olmasına rağmen zamanla birçok konuda sözünü geçirmesini bilmiş ve kendince bir otorite kurmayı başarmıştır. Günümüzde bile yaşanan sosyolojik bir sorun olan "erkek evlatların yaşlılıkta anne ve babaya bakar" düşüncesi Fatiş Hatun'u bir türlü terk etmez ve Tacettin'i sürekli olarak dizinin dibinde görmek ister.

\section{GÖÇ KENDİSI İLE BİRLİKTE YENİ BAŞLANGIÇLAR GETİRÍR}

Sigmund Freud'a göre yas çeken biri, zaman içerisinde bu yası "sağlıklı ve normal" bir biçimde tamamladıktan sonra söz konusu kaybına karşın çevrenin de etkisi ile bir geri çekilme yaşar. Bu ise yeni ilişkiler kurmanın ön koşullarından biridir (Schmitt ve Mees, 2000, s. 210). Bu tanımdan ve Freud'un da psikoanalitik bakış açısından yola çıkıldığında hem Hürriyet'in hem de Tacettin'in yaşamlarında içlerindeki acı her ne kadar da sönmemiş olsa bile yaşadıkları sosyal çevrenin etkisi, ailenin müdahalesi veya aile yaşamında dönüm noktası olan gelişmelerin sonucunda karşı cins ile yeni bir ilişsiye adım atarlar. Hürriyet karakteri Adana'da kendinden yaşça küçük Ahmet'e kaçarken, Tacettin kiracısının kızı Behire ile evlenir. Her iki ana karakterin yapmış oldukları evlilik gerçek aşk üzerine kurulmamıştır. Yeni bir aile kurmuş olmalarına rağmen yüreklerindeki ilk aşk bir türlü silinmez, aşk acıları, yasları sürekli olarak devam eder.

\section{AŞKIN MÜBADELESİ}

Her iki eserin ana karakteri ilk aşklarına kavuşamamanın ıstırabı içerisinde yaşamlarını sürdürür ve istemeseler dahi başka insanlarla evlenerek hayatlarına devam ederler. Hürriyet'in aşk1, İsmail'in intihar etmesi, Tacettin ve Patricia'nın aşkı ise mübadele mecburiyetinden ötürü tamamlanamamıştır. İsmail aşkının mübadelesini hayatı ile öder, Hürriyet ise "aşkın" mübadelesini bilinçaltındaki sorunları öteleme amacıyla Ahmet'e kaçıp evlenerek gerçekleştirir. Ancak Hürriyet Ahmet'e âşık değildir. Sadece içinde bulunduğu ve artık psikolojik olarak kaldıramayacağı ortamı terk 
etmek istemesinden ötürü Ahmet'e kaçar, ancak ömür boyu çekeceği manevi 1stırap bugüne kadar yaşamış olduklarından kat be kat fazla olur. Hürriyet, zengin ve görgülü İ́smail ile evleneceğine kaba saba, okumamış, şiddet uygulayan Ahmet ile evlenmek zorunda kalır. Fakat son nefesini verirken bile kocasına vasiyeti İsmail'in yanına gömülmektir. Hürriyet'in kızı, Hürriyet'in ölümünde çeyiz sandığında eski bir resmi bulup resimdeki kişinin kim olduğunu sorar babasına.

\begin{abstract}
"Yanına gidip eski bir fotoğrafi gösteriyorum. Bu kim? Gözleri doluyor. Ademelması birkaç kez inip çıkıyor. Duyulur duyulmaz bir sesle, "Annenin ilk nişanlısı "diyor. Sonra daha kısık, "İlk ve son sevdiği", diye mırıldanıyor. Son nefesini verirken bile, "Beni onun yanına gömün" dediği...Uzun ince boyuyla iki gündür dimdik ayakta duran bu seksenlik adamın omuzları ilk kez çöküyor. "Götüremedim...Götüremezdim...” sözcükleri dudaklarından dökülüyor.” (İçözü, 2012, s. 15)
\end{abstract}

Hürriyet, Ahmet ile evlenmiş ve ondan altı çocuk doğurmuş olmasına rağmen hâlâ ilk aşkı olan İsmail'in fotoğrafı ile avunur. Vasiyetinde İsmail'in yanına gömülmek varken, eşi onu oraya elbette gömemez. Fakat eserin anlatıcısı annesinin vefat toprağını yanında taşıyıp İsmail'in mezarına döker. "Artık annemin huzura kavuştuğunu biliyorum" (İçözü, 2012, s. 398) diyerek eser son bulur.

Aynı durum Tacettin için de söz konusudur. O da ilk aşkını bir türlü unutamaz, ancak çevre ve aile baskısı ile yeniden evlenmek zorunda kalır. Tacettin'in aşk mübadelesi tayini Keskin'e çıkmış olan ve Tacettin'in evini kiralayan Albay İhsan Beyin kızı Behire ile gerçekleşir. Her ne kadar da önceleri Behire ile evlenmek istemese de ailesinin onu ikna etmesi sonucu Behire ile evlenmek için ilk adım nişan töreni ile atılır.

"Hacı Ali Bey takacaktı yüzükleri. Kırmızı kadife elbisesinin içinde gelincikleri kıskandıracak güzellikteki Behire'ye, her zamankinden de yakışıklı görünen kara yağız oğluna hayranlıkla baktı [...] Yüzüklerden birini alıp Behire'nin parmağına geçirdi önce. Diğer yüzüğü de Tacettin'in parmağına taktı, hayırlı uğurlu olsun dilekleriyle, "Bu yüzükler saadet getirsin size” diyerek [...] Gözlerinin içi 1şılklıydı Behire'nin. Mesut görünüyordu [...] Tacettin'in duyguları ise karmakarışıktı. Behire'nin yüzüne bakamayışı mahcubiyetinden ya da bu ortamda yakışık almayacağını düşündüğünden değildi. Suçlu hissediyordu kendini. Hem Behire'ye hem de Patricia'ya karşı (Tan, 2013, s. 274-275).

Tacettin her ne kadar da yeni hayatına alışıyormuş gibi görünse de ilk aşkından bir türlü vaz geçemeyerek gizli de olsa onu ve oğlunu kalbinde yaşatmaya devam eder. Yukarıda da bahsedilen obsesyon Tacettin'in evlenmesinden sonra da ara vermeden sürer ve Tacettin'in 
kişiliği iki farklı kutba ayrılır. Birinci kişiliği yeni evlendiği Behire’ye karşın toplumsal rol gereği kocalığını sürdürmesi, ikinci kişiliği ise her gece çalışma odasına çekilerek belirli bir iş yapıyormuş görüntüsü altında çekmecesindeki Patricia ve Ali'nin fotoğrafı ile buluşması şeklinde gerçekleşir.

"Evet, her gece "gizli mabedim" dediği o odaya kapanıp Patricia ve Ali'yle buluşmaktan kendini alamıyordu Tacettin. Gerdek gecesi dışında hiç aksatmamıştı bu buluşmaları [...] İkiye ayrılmıştı ruhu. Duyduğu ezikliğin tesiriyle Behire'ye olabildiğince sıcak davranıyor, her istediğini anında yerine getiriyor, ilk gece söylediği gibi karısını mesut edebilmek için elinden gelen çabayı gösteriyordu... Bir adım geride duran ikinci kimliği, ancak bu gizli mabette ortaya çıkıyor, Patricia'nın tutkulu aşk1, Ali'nin biricik babası olarak onlarla hasret gideriyordu...Beraber çektirdikleri fotoğraflar, çalışma masasının kilitli çekmecesinde her akşam sabırsılıkla onun gelişini bekliyordu. Aynı sabırsızlık gün boyu Tacettin'in içini de yakıyor, Patricia ve Ali'ye kavuşmak için dakikaları sayıyordu." (Tan, 2013, s. 293-294)

Tacettin'in yaşantısı yıllarca böyle sürer, Behire gün gelip gerçekleri öğrenir belirli bir süre kocasına küser, ama sonra tekrar yuvasına döner. Özünde Tacettin aslında Behire'yi duygusal yönden aldatmıştır. Tacettin ve Behire'nin Doğan adında oğlu, Beyhan adında da bir kızı olur. Her ne kadar da ailesi ve çocukları için sorumlu bir baba ve sevgili bir eş olarak ailesine karşın görevlerini yerine getirse de ilk aşkını ve ilk göz ağrısı olan oğlu Ali'yi unutamaz. Tacettin yıllar sonra emekli olur, oğlu Doğan İstanbul'da hukuk eğitimi alırken kızı Beyhan ise liseye devam eder. Anneleri Behire Hanım çocuklarının yanında olmak için İstanbul'da onlarla birlikte yaşar. Tacettin emekli olarak Keskin'de yalnız kalır. Günün birinde oğlu Ali'nin ansızın çıkagelmesi Tacettin'in içinde küllenen ateşi yeniden canlandırır.

"Tacettin bahçede çalışırken demir parmaklıklı bahçe kapısının sesiyle irkildi [...] Kimi aramıştınız? diye sordu...Tacettin Bey’le görüşecektim dedi. Tacettin benim! Belli belirsiz gülümseme dolandı genç adamın yüzünde. "Adım Andoni” dedi. Ama Ali desem, belki daha iyi tanırsınız [...] Ali? Elindeki bahçe makasını fırlattı Tacettin. Ali'm diye haykırdı. Yer gök inledi sesinden. Yılların katmerleşmiş hasreti dudaklarında feryat, boğazında hıçkırık, gözlerinde sel olmuştu [...] oğluna sarılan Tacettin, anlat! dedi tüm susamışlığıyla, Patricia’yı anlat bana. Anneni anlat! Nerede? Ne yapıyor, nasıl? [...] Ali annesinin antika ve gümüş üzerine bir dükkân açtığını, kendisinin ise onunla beraber çalıştığını, evlendiğini ve Teodor adında bir oğlunun olduğunu anlattı...Tacettin dilinin ucuna gelip de bir türlü soramadığı soruyu sona bırakmıştı. Patricia...dedi. Sustu [...] Evlendi mi Patricia? [...] Hayır dedi Ali. Evlenmedi annem. Gerçekleri öğrendikten sonra anladım ki, ömrü boyunca yüreğinde taşımış seni. Sana ve aşkına sadık kaldı annem. Gözlerinden süzülen yaşlar bir kez 


\begin{abstract}
daha sel olup taştı Tacettin'in [...] İşlediği büyük cürmü itiraf eden bir suçlu gibi, "ben evlendim" diyerek başını öne eğdi. "Bir oğlum, bir kızım oldu" ...Evlendim ama Patricia'yı asla unutmadım ben! diye haykırdı. "Yüreğim ve ruhum ona aitti. Hep sevdim onu, her geçen saniye azalacağına çı̆̆ gibi büyüdü sevgisi [...] Tacettin fotoğrafları getirerek "Sizin yokluğunuzda bunlar yaşattı beni" diyerek fotoğraflardan daha yıpranmış olanını Ali'ye uzattı. Şu gördüklerin gözyaşlarımın izidir. Götür ver Patricia'ya. Kendisini görecektir o izlerde. Diğeri bende kalacak. O fotoğrafların da yeni izlerle yol yol olacağını söyle ona (Tan, 2013, s. 341-344).
\end{abstract}

Verilen bu alıntılarla, her iki eserin ana karakterlerinin aşkın mübadelesi diye betimlemek istenilen zorunlu duygu göçünün ne denli iz bırakarak yaşandığı görülür.

\title{
SONUÇ
}

Savaşların yıkıcılığı insanların belleklerine kazınır. Bu yıkıcılığın unutulmamasını sağlayan ve hatırlatıcı bir görev üstlenen araçlardan biri ise yazınsal eserlerdir. Yazınsal eserlerin bir türü olan romanlar yine kendi içinde işledikleri konulara göre çeşitlendirilirler. Toplumsal olayları ve ilişkileri genelde gerçeğine yakın yansıtmak isteyen romanlar çoğu zaman da kurgusal olarak yazılmaktadırlar. Bu çalışmada ele alınan eserler toplumsal bir olay olan Balkan Savaşları ve Birinci Dünya Savaşı olmak üzere tarih sayfasında iki önemli olay çerçevesinde anlatılmaktadır. Eserler anıya dayalı bellek romanları biçiminde yazılmış ve toplumsal ve kültürel çerçevenin koşullarını yansıtmıştır. Eserlerde işlenen her iki Savaş da henüz Türkiye Cumhuriyeti'nin kurulmasından önce dönemin Osmanlı topraklarında gerçekleşir, savaşların yıkıcılığı farklı halklarda onarılmaz acılar bırakır. Savaşların yıkıcılığı asker kaybının yanı sıra en çok sivil halkı etkiler. Savaşların gerçekleşmesine değin geçen sürede farklı halklar huzur içinde yaşarken, savaşların başlaması ile halkların birbirlerine karşı yaklaşımları da olumsuz bir hâl alır. Eserlerde yıllardan beri neredeyse kardeşlik bağı ile beraberce yaşan Rum ve Türk halkları savaşın etkisi ile kendi isteklerinin dışında birbirlerinden ayrılmak zorunda kalırlar. Öncelikle savaşın etkisi daha sonra ise Lozan Barış anlaşmasından kaynaklı mübadele sonucunda mübadiller can güvenliği endişesi içinde göç etmelidirler. Ele alınan ve karşılaştırılan eserler ile savaşın sonuçlarından biri olan göç unsuruna, elde edilen bulgular doğrultusunda göçün sebeplerine ve sonuçlarına değinilir. Göç unsuru ayrılmak zorunda kalınan yere belki de hiçbir zaman geri dönememeyi de beraberinde getirir. Ayrıca göç esnasında hastalıklar ve ölümler de gerçekleşir. Ahmet Asım Bey ve ailesi Selanik'ten ayrilıp İstanbul'a varma çabasında iken, göçün yaratmış olduğu olumsuz şartlara daha fazla dayanamayan ailenin en küçük çocuğu 
İradet seyahat esnasında ateşlenip hastalanır ve birkaç gün sonra vefat eder. Göç unsurunun bir diğer olumsuz yanı insanın sevdiğinden ayrılma travmasıdır. Zoraki göç yaşamış olan birinci eserin ana karakteri Hürriyet ile mübadele sonrası sevdiği kadını ve oğlunu göç etmekten alıkoyamayan ikinci eserin ana karakteri Tacettin aradıkları sevgi ve mutluluğu bulamaz, geride bıraktıklarını sürekli anarak obsesif davranışlar geliştirirler. Yaşadıkları ayrılık travması onlarda kalıcı obsesyonlar gelişmesine neden olur. Böylelikle manevi kayıp yaşayan ana karakterler psikolojik saplantılara maruz kalırlar. Hürriyet sabahtan akşama kadar temizlik yapar, Tacettin ise her akşam sevdiği kadın ve oğlunun resmi ile saatlerce sohbet eder. Göç edenler ayrıca göç ettikleri yerde yabancılaşırlar. Bu yabancılaşma hem yeni çevreye yönelik hem de bireyin kendisine yönelik gelişir. İnsanlar aynı etnik kökenden dahi olsalar vardıkları yerde yine de yabancı olarak algılanmakta ve uzun süreci uzun bir zaman almaktadır. Yabancıyı kabullenmeme ve yabancıyı dışlama her iki eserde genç kadınların kaderini değiştirmektedir. Hürriyet ilk önce sevdiği İsmail'in ailesinden daha sonra da kaçarak evlendiği Ahmet'in annesinden bir türlü istediği desteği göremez, horlanır ve sürekli dışlanmaya çalışılır. Tacettin'in sevdiği ve oğlunun annesi olan Patricia'da kayınvalidesi olmasını beklediği Fatiş Hatundan istenilen desteği görmeyince hayat seyri değişerek göç etmek zorunda kalır. Oysa ki bu genç kadınlar hemcinslerinden sevgi ve yakınlık görmüş olsalar idi, belki de Pürüzat Hanım oğlu İsmail'in intiharını, Fatiş Hatun ise Tacettin'in ömür boyu mutsuzluğunu engelleyebileceklerdi. Eserlerdeki anne karakterleri otoriter aile yapısına sahip geleneksel tarzda düşünce yapısını savunan ebeveynlerdir. Çocuklarını çok sevdiklerine inanan ve onların iyiliği için birtakım kararlar alan anneler aslında belki bilmeden en büyük günahları işlerler. Eserlerdeki annelerin toplumsal bakış açılarına göre görücü usulü ile ve kendilerinin arzuladığı gelin veya damat adayı ile evlenilmeli, sevginin ise evlendikten sonra zaten kendiliğinden yeşereceği savunulur. Her iki ana karakter sevdiklerine kavuşamadıkları için ömür boyu süren hasretler yaşar. Faklı insanlarla evlenseler, onlardan çocukları olsa bile hep kahrolur, vicdan azabı çeker ve bir yanları eksik kalır.

\section{KAYNAKÇA}

Armstrong, K. (2017). Tanrı'nın tarihi (3. bs.) (O. Özel, H. Koyukan ve K. Emiroğlu, Çev.). İstanbul: Pegasus.

Assmann, J. (1997). Kültürel bellek (Ayşe Tekin, Çev.). İstanbul: Ayrintı.

Aytaç, G. (2016). Karşılaştırmalı edebiyat bilimi. Ankara: DoğuBatı. 
ÇÜTAD Canan Tan ve Nur İçözü'nün Bellek Romanlarında Haziran 2021 Göç ve Aşk Mübadelesi Üzerine Bir Karşılaştırma

Boray, E. F. (2010). Öncesi ve sonrastyla cumhuriyet tarihi 2. İstanbul: Kum saati.

Budak, S. (2009) Psikoloji sözlüğü. Ankara: Bilim ve Sanat.

Butzer, G. and Jacob, J. (2012). Metzler lexikon literarischer symbole. 2. Erweiterte Auflage. Stuttgart: J.B. Metzler.

Doğan, İ. (2014). Sosyoloji, kavramlar ve sorunlar (13. bs.). Ankara: Pegem.

Erll, A. (2005). Kollektives gedächtnis und erinnerungskulturen. Stuttgart: J.B. Metzler.

Gardin, N., Olorenshaw, R., Gardin, J. ve Klein, O. (2014). Larousse semboller sözlüğü (B. Akşit, Çev.). İstanbul: Bilge.

Hall, S. (1987). Minimal selves. Post- Modernism and the Questions of Identity (L. Appignanesi, Der.). London: ICA Documents 6.

Hançerlioğlu, O. (1986). Toplumbilim sözlüğ̈̈. İstanbul: Remzi.

Harenberg, B. (1983). Chronik der Deutschen. Dortmund: Harenberg Kommunikation Verlag.

Hilal, R. (2001). Psikanaliz yazıları. Yalnızlık, 40. İstanbul: Bağlam.

İçözü, N. (2012). Hürriyet - bir sevda masalı. İstanbul: Altın Kitaplar.

Marshall, G. (2003). Sosyoloji sözlüğü (A. Osman ve K. Derya, Çev.). Ankara: Bilim ve Sanat.

Naumann, E. (1893). Vom Goldnen Horn zu den Quellen des Euphrat. München und Leipzig: Oldenburg.

Püsküllüoğlu, A. (1997). Arkadaş Türkçe sözlük. Ankara: Arkadaş.

Sazyek, H. (2013). Roman terimleri sözlüğü. Ankara: Hece.

Schmitt, A. and Mees, U. (2000). Emotionspsychologie. (Jürgen H. O., Harald A. E, Mandl, H., Ed.), Trauer 209, Weinheim: Beltz.

Tan, C. (2013). Hasret. İstanbul: Doğan.

Tarih IV. (1934). Türkiye Cumhuriyeti. T.T.T. Cemiyeti tarafindan yazılmıştır. İstanbul: Devlet Matbaası.

Wahrig, G. (1992). Deutsches wörterbuch. München: Bertelsmann Lexikon. 
ÇÜTAD Canan Tan ve Nur İçözü’nün Bellek Romanlarında Haziran 2021 Göç ve Aşk Mübadelesi Üzerine Bir Karşılaştırma

Yıldırım, A. (2017). Yeni Türkçe sözlük. 19. basım. İstanbul: Bilge Kültür Sanat.

Yıldırım, A. ve Şimşek, H. (2016). Sosyal bilimlerde nitel araştırma yöntemleri. Ankara: Seçkin.

Yıldırım, O. (2006). Türk-Yunan mübadelesi’nin öteki yüzü: diplomasi ve göç. İstanbul: Bilgi Üniversitesi yayınları 150. 